\title{
PENGARUH ALOKASI DANA DESA TERHADAP PELAKSANAAN PROGRAM PEMBANGUNAN DESA PADA KAMPUNG MALADUK DISTRIK KLASAFET KABUPATEN SORONG
}

\author{
Arce Yulita Ferdinandus \\ Universitas Victory Sorong \\ arceferdinandus@gmail.com
}

\begin{abstract}
The purpose of this research is to find out and analyze the influence of the allocation of village funds to the village development program in Kampung Maladuk Kalsafet District, Sorong Regency. By using a simple linear regression analysis tool, we can know the Village Fund Allocation (X) variable using the main indicators, namely; 1) Leadership accountability, 2) Process accountability, 3) Program accountability, and 4) Policy accountability, towards the Program affecting the Village Development program $(Y)$ which uses indicators namely; 1) Institutional Apparatus and Public Services, 2) Community Education, 3) Public Health, 4) Community Welfare, and 5) Transportation and Telecommunications Facilities. The Village Fund Allocation (ADD) which influences the Village development program becomes a study and benchmark for the village government in determining an effective Village development program for the community, efficient budget management and innovation towards the development of a modern Village development and beneficial for the Village community. After the existence of village funds the community began to feel a positive impact seen from the cooperation of the government and the community in improving the construction of village facilities and infrastructure such as the construction of roads, bridges, culverts, and improvements to village facilities aimed at improving the economy of the Kampung Maladuk community. Significant here means that the Hypothesis is accepted. That is, because $t$-count $>t$-table, it can be concluded that there is a positive influence between "the allocation of village funds to the village development program in the Maladuk village of Klasafet District, Sorong Regency received".
\end{abstract}

Keywords: village development and accountability

Abstrak

Tujuan dari penilitian ini adalah untuk mengetahui dan menganalisis pengaruh alokasi dana desa terhadap program pembangunan desa pada Kampung Maladuk Distrik Kalsafet Kabupaten Sorong. Dengan menggunakan alat analisa regresi linier sederhana maka, dapat diketahui variabel Alokasi Dana Desa (X) menggunakan indikator utama, yaitu; 1) Akuntabilitas kepemimpinan, 2) Akuntabilitas proses, 3) Akuntabilitas program, dan 4) Akuntabilitas kebijakan, terhadap Program mempengaruhi program Pembangunan Desa (Y) yang menggunakan indikator yaitu; 1) Aparatur Kelembagaan dan Pelayanan Publik, 2) Pendidikan Masyarakat, 3) Kesehatan Masyarakat, 4) Kesejahteraan Masyarakat, dan 5) Sarana Transportasi dan Telekomunikasi. Alokasi Dana Desa (ADD) yang mempengaruhi program pembangunan Desa menjadi kajian dan tolak ukur bagi pemerintah Desa dalam menentukan program pembangunan Desa yang efektif terhadap masyarakat, efisien terhadap pengelolaan anggaran dan inovasi terhadap perkembangan pembangunan Desa yang modern serta bermanfaat bagi masyarakat Desa. Setelah adanya dana desa masyarakat mulai merasakan adanya dampak yang 
positif terlihat dari adanya kerjasama pemerintah dan masyarakat dalam peningkatan pembangunan sarana dan prasarana desa seperti pembangunan jalan, jembatan, gorong-gorong, dan perbaikan fasilitas desa yang bertujuan meningkatkan perekonomian masyarakat Kampung Maladuk. Signifikan disini berarti Hipotesis diterima. Artinya, karena t-hitung > t-tabel, maka dapat disimpulkan bahwa Ada pengaruh positif antara" alokasi dana desa terhadap program pembangunan desa pada kampung Maladuk Distrik Klasafet Kabupaten Sorong diterima".

\section{Kata kunci: Akuntabilitas dan Pembangunan Desa}

\section{PENDAHULUAN}

Saat ini, pengelolaan keuangan desa menjadi salah satu isu strategis pada pemerintahan kabinet kerja di bawah kepemimpinan Presiden Jokowi. Baik isu tentang otonomi daerah khususnya desa, maupun peraturan yang melingkupinya. ADD merupakan dana yang dialokasikan oleh Pemerintah Kabupaten atau Kota untuk desa, yang bersumber dari bagian dana perimbangan keuangan pusat dan daerah yang diterima oleh Kabupaten atau Kota (PP No. 72 Tahun 2005 Pasal 1 ayat 11). Bagian dari dana perimbangan pusat dan daerah yang diterima oleh Kabupaten atau Kota untuk desa ini paling sedikit 10\% dari distribusi proporsional untuk setiap desa (Warsono, 2014).

Alokasi Dana Desa (ADD) bertujuan untuk mewujudkan pemerintah desa yang dapat mengelola pembangunan daerah berdasarkan prioritas anggaran mereka sendiri. Hal ini sesuai dengan poin ketiga dari Agenda Pembangunan Nasional dalam Perpres No. 2 tahun 2015 tentang RPJMN 2015-2019 yaitu untuk mewujudkan Nawa Cita dengan membangun Indonesia dari pinggiran dengan memperkuat daerah-daerah dan desa dalam kerangka Negara Kesatuan Republik Indonesia (Oktaresa, 2015: 16).

Jenis program kegiatan pembangunan Desa yang akan didanai melalui Alokasi Dana Desa diharapkan mampu untuk meningkatkan sarana pelayanan pelayanan masyarakat, berupa pemenuhan kebutuhan dasar, penguatan kelembagaan desa dan kegiatan lainnya yang dibutuhkan masyarakat desa dengan pengambilan keputusan melalui musyawarah.

Distrik klasafet merupakan distrik dari 32 distrik di Kabupaten Sorong yang merupakan hasil pemekaran dari Distrik induk Klamono dengan dasar peraturan daerah pemerintah Kabupaten Sorong nomor: 43 tahun 2013 tanggal 16 desember 2013 tentang pembentukan 14 distrik pemerintah daerah Kabupaten Sorong. Kampung Maladuk merupakan Kampung dari 5 kampung yang ada di Distrik Klasafet, merupakan hasil pemekaran dari kampung klamono pada tahun 2003 menjadi kampung definitive. 
Demikian dimana penulis ingin meneliti bagaimana pengolaan alokasi dana desa apakah berjalan sesuai dengan aturan yang telah ditetapkan atau tidak, apakah alokasi dana desa benarbenar dirasakan oleh masyarakat atau tidak. Alokasi dana desa diharapkan dapat mendorong pembangunan infrastruktur, seperti jalan desa, jembatan, maupun irigasi. Selan itu dana desa wajib digelontorkan untuk penyediaan pelayanan kesahatan dan pendidikan buat masyarakat. Hal lainnya, dana desa boleh dialirkan untuk peningkatan perekonomian desa.

Kategorisasi desa itu merujuk pada Indeks Pembangunan Desa (IPD). Instrumen ini mengukur pembangunan desa melalui lima dimensi, yang terdiri atas pelayanan dasasr, kondisi infrastruktur, transportasi, pelayanan umum, serta penyelenggaraan pemerintah.

Tabel 1

Program Pembangunan Kampung Maladuk Distrik Klasafet Kabupaten Sorong Tahun 2019

\begin{tabular}{|c|c|c|c|}
\hline No. & Program Pembangunan & Anggaran & Realisasi \\
\hline 1. & \begin{tabular}{ll}
\multicolumn{2}{l}{ Kesehatan } \\
- & Honor kader posyandu \\
- & Makanan tambahan
\end{tabular} & Rp. 10.000 .000 & $100 \%$ \\
\hline \multirow[t]{2}{*}{2.} & $\begin{array}{l}\text { Pendidikan } \\
\text { - } \quad \text { Bantuan buat gerson } \\
\text { - } \text { ATK } \\
\text { - } \text { Perlengkapan rumah } \\
\quad \text { tangga } \\
\text { - } \text { Barang konsumsi }\end{array}$ & Rp. 10.000 .000 & $100 \%$ \\
\hline & $\begin{array}{lll}- & \text { Honor petugas } \\
& \text { PAUD }\end{array}$ & Rp. 9.000.000 & $100 \%$ \\
\hline 3. & $\begin{array}{l}\text { Pelaksanaan Pembangunan } \\
\text { Desa (pekerjaan Umum } \\
\text { dan Penataan Ruang) } \\
\text { - Pemeliharaan } \\
\quad \begin{array}{l}\text { prasarana jalan desa } \\
\text { (gorong-gorong) }\end{array}\end{array}$ & Rp. 54.000.000 & $15 \%$ \\
\hline 4. & $\begin{array}{l}\text { Pemeliharaan Jalan Desa } \\
\begin{array}{c}\text { - } \\
\text { Pembangunan jalan } \\
\text { sertu }\end{array} \\
\end{array}$ & Rp. 116.170.000 & $0 \%$ \\
\hline 5. & $\begin{array}{l}\text { Kawasan } \\
\text { dukungan Pemukiman } \\
\text { Pembangunan } \\
\text { - Pelaksanaan } \\
\text { rumah tidak layak } \\
\text { huni ukuran 6 X } 7 \\
\text { (4 Unit) }\end{array}$ & Rp. 544. 000.000 & $25 \%$ \\
\hline
\end{tabular}

Sumber: RKPDesa Maladuk, Distrik Klasafet, 2019. 
Berdasarkan latar belakang tersebut di atas maka rumusan masalah yang akan di teliti adalah Bagaimana pengaruh alokasi dana desa terhadap program pembangunan desa pada Kampung Maladuk Distrik Kalsafet Kabupaten Sorong.

\section{TELAAH LITERATUR}

Sesuai dengan keuangan desa menurut UU No. 6 Tahun 2014 adalah semua hak dan kewajiban desa yang dapat dinilai dengan uang, serta segala sesuatu berupa uang dan barang yang berhubungan dengan pelaksanaan hak dan kewajiban. Hak dan kewajiban ini dapat menimbulkan pendapatan, belanja, pembiayaan dan pengelolaan keuangan desa. Berdasarkan data secara nasional pencairan dana Desa dari 5 tahun terakhir besarnya anggaran Dana Desa tiap tahunnya selalu mengalami kenaikan. Dari 20.766,2 Trilliun Rupiah di tahun 2015, menjadi 47.684,7 Trilliun Rupiah di tahun 2016. Sedangkan di tahun 2017 mencapai 81.184,3 Trilliun Rupiah dan di perkirakan hingga tahun 2019 anggaran Dana Desa ini akan mencapai 111.840,2 Trilliun Rupiah (DJPK, 2015). Kenaikan ini dapat dilihat dalam table dibawah ini:

\section{Tabel 2}

Pekembangan Jumlah Bantuan Dana Desa

\begin{tabular}{|c|c|c|c|c|c|c|}
\hline \multirow{2}{*}{ NO } & \multirow{2}{*}{ ITEM } & \multicolumn{5}{|c|}{ DATA TAHUNAN } \\
\cline { 3 - 7 } & & $\mathbf{2 0 1 5}(\mathbf{R p})$ & $\mathbf{2 0 1 6}(\mathbf{R p})$ & $\mathbf{2 0 1 7}(\mathbf{R p})$ & $\mathbf{2 0 1 8}(\mathbf{R p})$ & $\mathbf{2 0 1 9}(\mathbf{R p})$ \\
\hline $\mathbf{1}$ & Dana Desa (DD) & $20.766,2 \mathrm{~T}$ & $47684,7 \mathrm{~T}$ & $81.184,3 \mathrm{~T}$ & $103.791 \mathrm{~T}$ & $111.840,2 \mathrm{~T}$ \\
\hline $\mathbf{2}$ & $\begin{array}{c}\text { Rata - rata DD per } \\
\text { Desa }\end{array}$ & $280,3 \mathrm{Jt}$ & $643,6 \mathrm{Jt}$ & $1.095,7 \mathrm{Jt}$ & $1.400,8 \mathrm{Jt}$ & $1.509,5 \mathrm{Jt}$ \\
\hline
\end{tabular}

Sumber: Direktorat Jenderal Perimbangan Keuangan RI

Siklus pengelolaan berdasarkan Undang-Undang No. 6 Tahun 2014, meliputi:

1) Penyiapan Rencana; 2) Musrenbang desa yang melibatkan pemerintah desa, BPD, dan kelompok masyarakat yang diawali dengan tingkat dusun hingga tingkat desa;

3) Penetapan Rencana, rencana disini merupakan pedoman APB Desa;

4) Penetapan APB Desa;

5) Pelaksanaan Pembangunan, melibatkan seluruh masyarakat secara swakelola;

6) Pertanggungjawaban, pemerintah desa wajib menyampaikan laporan dalam musyawarah pembangunan desa;

7) Pemanfaatan dan Pemeliharaan.

Pengelolaan Dana Desa meliputi tiga kegiatan penting yaitu Perencanaan, Pelaksanaan, dan Pertanggungjawaban (Akuntabilitas). 
Penilitian ini mengangkat akuntabilitas sebagai indikator utama dalam mengukur pengaruh pengelolaan Alokasi Dana Desa terhadap program pembangunan Desa. Untuk itu akan dijelaskan ap aitu pertanggungjawaban (Akuntabilitas) dibawah ini:

\section{Akuntabilitas}

Akuntabilitas adalah kewajiban untuk memberikan pertanggungjawaban atau menjawab dan menerangkan kinerja dan tindakan seseorang berbadan hukum pimpinan suatu organisasi kepada pihak yang memiliki hak atau berkewenangan untuk meminta keterangan atau pertanggungjawaban (Astuti, 2016). Sedangkan menurut Krina (2003), “akuntabilitas berhubungan dengan kewajiban dari institusi pemerintah maupun para aparat yang bekerja di dalamnya untuk membuat kebijakan maupun melakukan aksi yang sesuai dengan nilai yang berlaku maupun kebutuhan masyarakat (Krina, 2003). Akuntabilitas dapat pula diartikan sebagai prinsip pertanggungjawaban publik yang menunjukkan bagaimana pejabat publik menggunakan sumber daya publik dan tanggung jawab ketika mereka menganggarkan dan melaporkan sehingga pejabat publik dapat memberikan penjelasan tentang pengeluaran saat diperlukan.

Untuk dapat menerapkan prinsip akuntabilitas tersebut diperlukan berbagai sumber daya dan sarana pendukung, diantaranya adalah Sumber Daya Manusia (SDM) yang kompeten serta dukungan sarana teknologi informasi yang memadai dan dapat diandalkan (Oktaresa, 2015: 17). Akuntabilitas publik menuntut adanya pembatasan tugas yang jelas dan efisien dari para aparat birokrasi. Prinsip akuntabilitas publik adalah suatu ukuran yang menunjukkan seberapa besar tingkat kesesuaian penyelenggaraan pelayanan dengan ukuran nilai-nilai atau norma-norma eksternal yang dimiliki oleh para stakeholders yang berkepentingan dengan pelayanan tersebut (Krina, 2003).

Sedangkan dalam konteks keuangan, akuntabilitas merupakan pertanggungjawaban mengenai integritas keuangan, pengungkapan, dan ketaatan terhadap peraturan perundangan. Sasaran pertanggungjawaban ini adalah laporan keuangan yang disajikan dan peraturan yang berlaku yang mencakup penerimaan, penyimpanan, dan pengeluaran uang oleh instansi pemerintahan (LAN \& BPKP, 2003).

Akuntabilitas berarti menggambarkan proses penganggaran dan pelaporan, mulai dari perencanaan sampai pelaksanaan dalam pengelolaan Alokasi Dana Desa (ADD), harus benarbenar dilaporkan dan dipertanggungjawabkan kepada yang berkepentingan, dan juga dapat diakses oleh masyarakat di wilayah tersebut. 


\section{Program Pembangunan Desa}

Secara lansung program pembangunan desa berkaitan dengan perencanaan pembangunan desa. Sebagaimana diatur di dalam Peraturan Menteri Dalam Negeri No. 114 tahun 2014, tentang Pedoman Pembanguna Desa, disebutkan bahwa Perencanaan pembangunan desa adalah proses tahapan kegiatan yang diselenggarakan oleh pemerintah Desa dengan melibatkan Badan Permusyawaratan Desa dan unsur masyarakat secara partisipatif guna pemanfaatan dan pengalokasian sumber daya desa dalam rangka mencapai tujuan pembangunan desa. Lebih lanjut dijelaskan, Pembangunan Partisipatif adalah suatu sistem pengelolaan pembangunan di desa dan kawasan perdesaan yang dikoordinasikan oleh kepala Desa dengan mengedepankan kebersamaan, kekeluargaan, dan kegotongroyongan guna mewujudkan pengarusutamaan perdamaian dan keadilan sosial.

Dalam rangka perencanaan dan pelaksanaan pembangunan Desa, pemerintah Desa didampingi oleh pemerintah daerah kabupaten/kota yang secara teknis dilaksanakan oleh satuan kerja perangkat daerah kabupaten/ kota. Untuk mengoordinasikan pembangunan Desa, kepala desa dapat didampingi oleh tenaga pendamping profesional, kader pemberdayaan masyarakat Desa, dan/atau pihak ketiga. Camat atau sebutan lain akan melakukan koordinasi pendampingan di wilayahnya. Pembangunan desa mencakup bidang penyelenggaraan pemerintahan Desa, pelaksanaan pembangunan Desa, pembinaan kemasyarakatan Desa dan pemberdayaan masyarakat Desa (Kessa, 2015).

\section{METODE PENILITIAN}

Penelitian ini dilaksanakan di Kampung Maladuk Distrik Klasafet Kabupaten Sorong. Jenis penelitian dalam penelitian ini adalah deskriptif kuantitatif, Data Primer, yaitu data yang diperoleh sebagai hasil dari kuesioner atau angket yang dibagikan penulis kepada 37 Kepala Keluarga Masyarakat Kampung Maladuk Distrik Klasafet yang menjadi sampel penelitian. Data Sekunder, yaitu data yang diperoleh melalui catatan - catatan organisasi dan literatur - literatur kepustakaan yang berhubungan dengan masalah yang ditulis.

Variabel Independen utama meliputi sebagai berikut:

\section{Akuntabilitas Kepemimpinan}

a. Penghindaran penyalahgunaan pengelolaan ADD

b. Kepatuhan terhadap peraturan yang mengatur pengelolaan ADD

2.Akuntabilitas Proses 
a. Kesesuaian pengelolaan ADD dengan prosedur yang berlaku

b. Upaya proses pengelolaan yang dilakukan pada pencapaian tujuan.

3. Akuntabilitas Program

a. Kesesuaian program yang dibiayai ADD dengan kebutuhan masyarakat.

b. Pelaksanaan program ADD

4. Akuntabilitas Kebijakan

a. Penyusunan pengelolaan ADD

b. Laporan pertanggungjawaban pengelolaan ADD

Dalam menyusun tolok ukur / indikator program pembangunan Desa, digunakan 9 (sembilan) indikator, yaitu: (i) Kapasitas Aparatur dan Jangkauan Pelayanan Publik, (ii) Kekayaan dan Keuangan Desa, (iii) Sarana Perekonomian Desa, (iv) Sarana Transportasi dan Telekomunikasi, (v) Kelembagaan dan Partisipasi Masyarakat Desa, (vi) Kesejahteraan Masyarakat, (vii) Pendidikan Masyarakat, (viii) Kesehatan Masyarakat, dan (ix) Kesejahteraan Keluarga. Secara operasional, ke-9 indikator tersebut dapat dijabarkan sebagai berikut (Mulyanto, 2013):

Namun penulis mengangkat 4 indikator yang menjadi tolak ukur untuk melihat program pembangunan Desa dipengaruhi oleh pengelolaan Alokasi Dana Desa (ADD), yaitu:

1. Aparatur Kelembagaan dan Pelayanan Publik

2. Pendidikan Masyarakat

3. Kesehatan Masyarakat

4. Kesejahteraan Masyarakat

5. Sarana Transportasi dan Telekomunikasi.

\section{Uji Validitas dan Reliabilitas}

\section{a. Uji Validitas}

Untuk menguji validitas dan reliabilitas kuesioner pernyataan dari promosi dan keputusan pembelian. Validitas instrument dalam penelitian ini terdiri dari 2 (dua) yaitu validitas isi dan validitas butir

\section{b. Uji Reliabilitas}

Uji reliabilitas bertujuan untuk mengetahui apakah alat pengumpul data pada dasarnya menunjukkan tingkat ketepatan, keakuratan kestabilan atau konsistensi alat tersebut dalam mengungkapkan gejala-gejala tertentu dari sekelompok individu, walaupun dilakukan pada 
waktu yang berbeda. Uji reliabilitas dilakukan terhadap pertanyaan yang telah valid. Rumus yang dipakai adalah untuk menguji reliabilitas dalam penelitian adalah Cronbach' Alpha yang penyelesaianya dilakukan dengan membandingkan antara $\mathrm{r}_{\text {alpha }}$ dan $\mathrm{r}_{\text {tabel }}$.

\section{Uji Statistik}

Sebelum dilakukan perhitungan guna menguji model kasualitas dengan menggunakan metode analisis regresi linier sederhana, maka diperlukan data hasil penelitian yang telah diuji dan memenuhi seluruh persyaratan.

\section{a. Uji $\mathbf{t}$-test}

Uji statistik t pada dasarnya menunjukkan seberapa jauh pengaruh satu variabel penjelas secara individual dalam menerangkan variasi variabel terikat. Rumus yang digunakan untuk menguji hipotesis tersebut adalah :

$\mathrm{t}=\frac{r s \sqrt{n-2}}{\sqrt{1-r} s 2}$

Keterangan :

$\mathrm{n}=$ jumlah data

$\mathbf{r}=$ koefisien korelasi

Kriteria Keputusannya adalah :

a. Jika thitung $>\mathrm{t}$ tabel, dan sig $<0,05$ maka hipotesis diterima.

b. Jika $\mathrm{t}$ hitung $<\mathrm{t}$ tabel, dan sig $>0,05$ maka hipotesis ditolak.

c. Taraf signifikan $=5 \%$

d. Derajat kebebasan $(\mathrm{df})=\mathrm{n}-2$

\section{b. Uji F}

Uji F digunakan untuk menentukan apakah secara serentak variabel independen mampu menjelaskan variabel dependen dengan baik atau apakah variabel independen mempunyai pengaruh yang signifikan terhadap variabel dependen secara bersama-sama. Rumus yang digunakan untuk menguji hipotesis tersebut adalah :

$$
\text { Fhitung }=\frac{R^{2} /(k-1)}{\left(1-R^{2}\right) / n-k}
$$

Dimana :

$$
\begin{aligned}
& \mathrm{R}^{2}=\text { koefisien determinasi } \\
& \mathrm{n}=\text { Banyaknya sampel (observasi) }
\end{aligned}
$$


$\mathrm{K}=$ Banyaknya parameter atau koefisien regresi plus konstanta

Kriteria Pengujian :

a. Apabila nilai F hitung < F tabel, maka Hipotesis ditolak. Artinya semua koefisien regresi secara bersama-sama tidak signifikan pada taraf signifikansi $5 \%$

b. Apabila nilai $\mathrm{F}$ hitung > F tabel, maka Hipotesis diterima. Artinya semua koefisien regresi secara bersama-sama signifikan pada taraf signifikansi $5 \%$.

\section{Analisa Regresi Linear Sederhana}

Yaitu untuk mengukur seberapa jauh pengaruh alokasi dana desa terhadap program pembangunan desa, dengan analisa yang digunakan analisa regresi linear sederhana maka dapat dirumuskan sebagai berikut :

$$
\mathbf{Y}=\mathbf{a}+\mathbf{b} \cdot \mathbf{X}
$$

Dimana :

$$
\mathrm{Y} \quad=\text { Program Pembangunan Desa }
$$

$\mathrm{a}=$ Bilangan Konstanta

$\mathrm{b}=$ Koefisien regresi

$\mathrm{X}=$ Alokasi Dana Desa

\section{Uji Koefisien Determinasi $\left(\mathbf{R}^{2}\right)$}

Koefisien determinasi $\mathrm{R}^{\mathbf{2}}$ digunakan untuk mengetahui berapa persen Variasi Variabel Dependent dapat dijelaskan oleh variasi variabel independent. Nilai $\mathrm{R}^{2}$ ini terletak antara 0 dan 1. Bila nilai $\mathrm{R}^{2}$ mendekati 0 , berarti sedikit sekali variasi variabel dependen yang diterangkan oleh variabel independen. Jika nilai $\mathrm{R}^{2}$ bergerak mendekati 1berarti semakin besar variasi variabel dependent yang dapat diterangkan oleh variabel independen jika ternyata dalam perhitungan nilai $\mathrm{R}^{2}$ sama dengan 0 maka ini menunjukan bahwa variabel dependent tidak bisa dijelaskan oleh variabel independen.Untuk mengelolah data guna membahas dan menarik kesimpulan penelitian, peneliti menggunakan bantuan Komputer melalui program SPSS 21.00 (Statistical Package for Social Science). 


\section{HASIL DAN PEMBAHASAN}

\section{Tabel 3}

Uji validitas butir-butir pertanyaan

variabel penelitian

\begin{tabular}{|l|l|l|l|}
\hline Variabel Butir Pertanyaan & r-hitung & r-tabel & Status Butir \\
\hline Alokasi Dana Desa : & & & \\
1. Infrastruktur yang baik & 0,794 & 0,274 & Valid \\
2. Fasilitas umum yang memadai & 0,716 & 0,274 & Valid \\
3. Akses informasi & 0,749 & 0,274 & Valid \\
4. Kualitas informasi & 0,781 & 0,274 & Valid \\
5. Pendapatan penduduk & 0,734 & 0,274 & Valid \\
\hline Program Pembangunan Desa : & & & \\
1. Akuntabilitas kepemimpinan & 0,416 & 0,274 & Valid \\
2. Akuntabilitas proses & 0,612 & 0,274 & Valid \\
3. Akuntabilitas program & 0,374 & 0,274 & Valid \\
4. Akuntabilitas kebijakan & 0,412 & 0,274 & Valid \\
\hline
\end{tabular}

Sumber : data primer diolah 2017

Berdasarkan Tabel 4.13 dapat diketahui bahwa hasil perhitungan $r$ hitung semua lebih besar dari $r$ tabel product moment (Pearson) yaitu pada $\mathrm{df}=(\mathrm{n}-2)$ yaitu: $37-2=35$, dan $\alpha=5 \%$ sebesar 0.274. Hal ini berarti alat ukur dari variabel yang digunakan adalah valid.

\section{a. Reliabiltas}

Reliabilitas adalah suatu indikasi untuk mengukur sejauh mana hasil suatu pengukuran dapat dipercaya. Apabila pertanyaan diulangi pada subyek yang sama dengan waktu yang berbeda diperoleh hasil yang relatif sama. Koeffisien Alpha Cronbach yang digunakan untuk mengukur reliabilitas disajikan pada Tabel berikut:

\section{Tabel 4}

Pengujian reliabilitas butir-butir pertanyaan

variabel penelitian

\begin{tabular}{|l|l|l|l|}
\hline Variabel & $\begin{array}{l}\text { Alpha } \\
\text { Cronbach } \\
\text { Hitung }\end{array}$ & $\begin{array}{l}\text { Alpha } \\
\text { Cronbach } \\
\text { Yang } \\
\text { Disyaratkan }\end{array}$ & Keterangan \\
\hline Alokasi Dana Desa(X) & 0,900 & 0.60 & Reliabel \\
\hline Program Pembangunan Desa $(\mathrm{Y})$ & 0,670 & 0.60 & Reliabel \\
\hline
\end{tabular}

Sumber : data primer diolah 2019

Berdasarkan Tabel 4.2 dapat diketahui bahwa Hasil perhitungan Alpha Cronbach yang dapat dilihat pada lampiran III, terlihat hasil perhitungan semua lebih besar dari 0.60 hal ini berarti pengukuran relatif konsisten apabila pengukuran diulangi dua kali atau lebih. Berdasarkan 
pengujian validitas dan reliabilitas yang telah dilakukan, dapat disimpulkan semua butir-butir pertanyaan valid dan reliabel, hal ini berarti semua butir-butir pertanyaan yang diajukan dalam penelitian ini dapat dipergunakan untuk analisis selanjutnya.

\section{b. Uji Normalitas Data}

Uji normalitas data ini tujuannya dilakukan sebelum data diolah berdasarkan model model penelitian. Uji normalitas ini bertujuan untuk mengetahui distribusi data dalam variabel yang akan digunakan dalam penelitian. Data yang baik dan layak digunakan dalam penelitian adalah data yang memiliki distribusi normal.

Normalitas data dapat dilihat dengan beberapa cara, namun dalam penelitian ini peneliti menggunakan histogram display normal curve. Normalitas data bila dilihat dengan cara ini dapat ditentukan berdasarkan bentuk gambar kurva. Data dikatakan normal jika bentuk kurva memiliki kemiringan yang cenderung imbang, baik pada sisi kiri maupun sisi kanan, dan kurva berbentuk menyerupai lonceng yang hampir sempurna. Semakin mendekati 0 nilai skewness gambar kurva cenderung memiliki kemiringan yang seimbang. Adapun gambar kurva normal dalam penelitian ini dapat dilihat pada gambar dibawah ini :

\section{Gambar 1}

\section{Uji Normalitas Data}

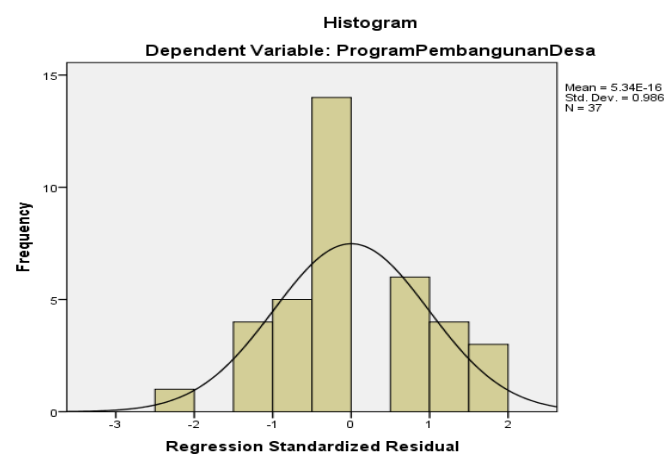

Gambar 4.1 histogram dengan kurva normal variabel X (Alokasi Dana Desa) pada hasil output SPSS mendukung hasil dari nilai skewness yang mendekati 0. Kurva variabel X (Alokasi Dana Desa) tidak condong (miring) ke kiri maupun ke kanan, namun cenderung di tengah dan berbentuk seperti lonceng. Jadi variabel X (Alokasi Dana Desa) memiliki kecenderungan terdistribusi secara normal. 


\section{c. Uji Simultan (F)}

Uji F ini bertujuan untuk mengetahui secara bersama-sama variabel independen terhadap variabel dependen. Hasil F-test ini dapat dilihat lengkapnya pada output SPSS pada tabel dibawah ini :

\section{Tabel 5}

Rangkuman Hasil Analisis Statistik

\begin{tabular}{|l|l|l|c|}
\hline \multicolumn{1}{|c|}{ Variabel } & Koefisien & \multicolumn{1}{c|}{ thitung $_{\text { }}$} & Signifikansi \\
\hline Konstanta & 1,764 & 3,817 & 0,001 \\
\hline Alokasi Dana Desa & 0,575 & 5,095 & 0,000 \\
\hline $\mathrm{R}$ & 0,653 & \multicolumn{3}{|l}{} \\
Adjusted $\mathrm{R}^{2}$ & 0,426 & \\
F Hitung & 25,957 &
\end{tabular}

Sumber: Data Primer di olah

Dalam ringkasan Tabel 4.15 hasil uji simultan (uji F), dihasilkan F-hitung 25,957 > Ftabel 4,121, artinya signifikan (df1 =2 - $1=1$ dan df2 = $37-2=35$ ). Signifikan disini berarti hipotesis diterima yang berbunyi "Ada pengaruh positif antara" alokasi dana desa terhadap program pembangunan desa pada kampung Maladuk Distrik Klasafet Kabupaten Sorong diterima".

\section{d. Uji Parsial (t)}

Uji t ini bertujuan untuk mengetahui secara bersama-sama variabel independen terhadap variabel dependen. Hasil t-test ini dapat dilihat lengkapnya pada output SPSS pada tabel 4.15. Dalam ringkasan Tabel 4.15 hasil uji parsial (uji t), dihasilkan t-hitung alokasi dana desa thitung 5,095 > t-tabel 1.689, artinya signifikan (df1 =2 $-1=1$ dan df2 = $37-2=35$ ). Signifikan disini berarti Hipotesis diterima. Artinya, karena t-hitung > t-tabel, maka dapat disimpulkan bahwa Ada pengaruh positif antara" alokasi dana desa terhadap program pembangunan desa pada kampung Maladuk Distrik Klasafet Kabupaten Sorong diterima".

\section{e. Analisis Regresi Sederhana}

Analisis regresi dalam penelitian ini digunakan untuk menguji alokasi dana desa terhadap program pembangunan desa pada kampung Maladuk Distrik Klasafet Kabupaten Sorong. Penyelesaian model regresi linier sederhana dilakukan dengan bantuan Program SPSS for Windows Release 12.0 dan perhitungan selengkapnya dapat dilihat pada tabel 4.16. Adapun hasilnya adalah sebagai berikut :

$$
\underline{Y=1.764+0.575 X+e}
$$


Persamaan menunjukkan bahwa alokasi dana desa dipengaruhi oleh program pembangunan desa.

a. Nilai konstanta sebesar 1.674 menyatakan jika ada peningkatan alokasi dana desa, maka skor alokasi dana desa akan naik sebesar 2,299 satuan.

b. Nilai koefisien program pembangunan desa sebesar 0,575 menyatakan jika terjadi peningkatan program pembangunan desa dalam alokasi dana desa pada kampung Maladuk Distrik Klasafet Kabupaten Sorong dalam meningkatkan program pembangunan desa akan mengalami peningkatan sebesar 0.575 .

Berdasarkan hasil analisis regresi linier sederhana dalam penelitian ini menunjukkan adanya pengaruh positif antara alokasi dana desa dalam meningkatkan program pembangunan desa diperoleh $\mathrm{Y}=1.764+0.575 \mathrm{X}+\mathrm{e}_{-}$yang artinya Nilai konstanta sebesar 1.674 menyatakan jika ada peningkatan alokasi dana desa, maka skor alokasi dana desa akan naik sebesar 2,299 satuan. Nilai koefisien program pembangunan desa sebesar 0,575 menyatakan jika terjadi peningkatan program pembangunan desa dalam alokasi dana desa pada kampung Maladuk Distrik Klasafet Kabupaten Sorong dalam meningkatkan program pembangunan desa akan mengalami peningkatan sebesar 0.575 . Harga koefisien determinasi digunakan untuk mengetahui besarnya pengaruh indikator indikator alokasi dana desa terhadap program pembangunan desa pada kampung Maladuk Distrik Klasafet Kabupaten Sorong dimana diketahui koefisien determinasi $\left(\mathrm{r}^{2}\right)$ sebesar 0,426 atau $42,60 \%$. Hal ini berarti bahwa pengaruh alokasi dana desa terhadap program pembangunan desa pada kampong Maladuk Distrik Klasafet Kabupaten Sorong sebesar $42,60 \%$, sedangkan selebihnya yaitu $57,40 \%$ dipengaruhi oleh faktor lain yang tidak ditelit dalam penelitian ini.

Hasil uji parsial (uji t), dihasilkan t-hitung alokasi dana desa t- hitung 5,095 > t-tabel 1.689, artinya signifikan ( $\mathrm{df} 1=2-1=1$ dan $\mathrm{df} 2=37-2=35$ ). Signifikan disini berarti Hipotesis diterima. Artinya, karena t-hitung > t-tabel, maka dapat disimpulkan bahwa Ada pengaruh positif antara" alokasi dana desa terhadap program pembangunan desa pada kampung Maladuk Distrik Klasafet Kabupaten Sorong diterima”. 


\section{KESIMPULAN DAN SARAN}

\section{Kesimpulan}

Pemberdayaan masyarakat Kampung Maladuk sebelum adanya dana desa memang belum mampu dirasakan oleh masyarakat secara keseluruhan. Selain itu, keadaan infrastruktur sebagai salah satu penunjang akan kegiatan pertumbuhan masyarakat dalam berbagai bidang, keadaanya belum begitu baik. Hal ini dapat dilihat dari keadaan beberapa jalan penghubung antar desa dibeberapa wilayah yang masih rusak, begitu juga jembatan, serta belum ada pembangunanpembangunan yang ditujukan untuk meningkatkan pemberdayaan masyarakat. Setelah adanya dana desa masyarakat mulai merasakan adanya dampak yang positif terlihat dari adanya kerjasama pemerintah dan masyarakat dalam peningkatan pembangunan sarana dan prasarana desa seperti pembangunan jalan, jembatan, gorong-gorong perbaikan fasilitas desa dan kegiatan pemberdayaan yang bertujuan meningkatkan perekonomian masyarakat Kampung Maladuk. Sumber daya yang di alokasikan untuk pembangunan selama ini sudah terlihat mengalami perubahan walaupun belum sepenuhnya.

\section{Saran}

Berdasarkan hasil penelitian yang telah dibahas pada bab sebelumnya maka peneliti menyarankan hal-hal sebagai berikut

1. Pemberdayaan masyarakat alangkah lebih baiknya tidak hanya mengarah pada pembangunan infrastruktur saja, penggalian potensi yang ada di masyarakat harus mulai dilakukan atau dilaksanakan, agar masyarakat mampu berkembang. Contohnya pembuatan kelompok-kelompok Ekonomi kreatif, pengadaan mekanisme pasar desa yang bertujuan untuk meningkatkan perekonomian yang mandiri.

2. Masyarakat desa untuk kedepanya harus memiliki kemauan dan kerjasama yang baik dengan pemerintah dalam upaya meningkatkan kemandirian dan terlaksananya pemberdayaan masyarakat serta baiknya masyarakat mampu menggali lebih dalam lagi potensi apa yang ada di masyarakat, sehingga kedepannya diharapkan mampu meningkatkan kualitas dan taraf hidup masyarakat itu sendiri. 


\section{DAFTAR PUSTAKA}

Astuti, Titiek Puji dan Yulianto. (2016). Good Governance Pengelolaan Keuangan Desa Menyongsong Berlakunya Undang-Undang No. 6 Tahun 2014. Berkala Akuntansi dan Keuangan Indonesia, Vol. 1 No. 1:1-14.

Direktorat Jenderal Perimbangan Keuangan RI. (2015). Kebijakan Dana Desa TA 2016. 7 Desember 2016. www.djpk.kemenkeu.go.id.

Kessa, Wahyudin. 2015. Perencanaan Pembangunan Desa. Jakarta: Kementrian Desa, Pembangunan Daerah Tertinggal, dan Transmigrasi Republik Indonesia.

Krina P, Loina Lalolo. (2003). Indikator dan Alat Ukur Prinsip Akuntabilitas, Transparansi dan Partisipasi. Bappenas: Jakarta.

Lembaga Administrasi Negara dan Badan Pengawasan Keuangan dan Pembangunan. (2000). Akuntabilitas dan Good Governance. Bogor.

Mulyanto. (2013). The Model of Index for Massuring the Progress of Rural Development at Autonomy Era in Indonesia: A Pilot Priject in Klaten Regency, Central Java. Paperpresented in the 38th Conference of the Federation of ASEAN Economic Associations (FAEA), Singapore, 27th29th November.

Oktaresa, B. (2015). Analisis Hubungan Pengalaman, Pengetahuan Mendeteksi Kecurangan, dan Skeptisme Profesional dengan Kemampuan Pendeteksian Kecurangan pada Perwakilan BPKP Provinsi Riau. Jurnal Sekolah Tinggi Ilmu Akuntansi Negara Tangerang Selatan.

Republik Indonesia. (2014). Undang-Undang No. 6 Tahun 2014 Tentang Desa. Jakarta.

Santoso, Singgih. 2001. SPSS Versi 11,5 Mengolah Data Statistik Secara Profesional. Jakarta: PT Elex Media Komputindo.

Soemantri, BambangTrisantono. (2011). Pedoman Penyelenggaraan Pemerintahan Desa. Bandung: Fokus Media.

Warsono, Hardi dan Ruksamin. (2014). The Obstacles of Implementation of Village Allocation Fund Program in the North Konawe Southeast Sulawesi. Journal of Management and Sustainability Vol. 4 No. 3, ISSN 1925-4725 E-ISSN 1925-4733.

Yuliati, Yayuk dan Mangku Poernomo. 2003. Sosiologi Pedesaan. Jakarta: Lapera 